Optimization of Tourism Development in Egypt by Examining the Tourism Development

\title{
Experience in UAE
}

\author{
Hala Nabil Hilaly \\ Faculty of Tourisun and Hotels - Alexandria University
}

\begin{abstract}
Introduction
The fourism industry is playing an increasingly significant role in the country's national economy. Tourism in Egypt is a significant contributor to GDP and enployment, with direct shares of $3.5 \%$ and $12.6 \%$ respectively (Information and Decision Support Centre, 2007).

Egypt's tourism sector has regained momentum and has been able to realize a satisfactory performance over the last few years in terms of volume, valtie-ndded and foreign revenues.

Certain deyeloping countries of the world have achieved axceptional tourism development and continue to do so. United Arab of Emirates, an energing tourist cotntry, establishes itself as a relatively popular destination with a high tourism growth (EIU, 2003b). It is now consideted one of the most important tourist destinations in the Middle East. Dubai's tourism development has witnessed a strong increase. The manner in which it has done so is described in terns of the factors facilitating destination developiment if present or intibiting it when found wanted.

Although, having an incomparable array of nataral and cultural assets, as well as a long history of tourism, the first global tourism conpetition indax issued in March 2007 places Egypt as the $58^{\text {th }}$ country within the 134 countries

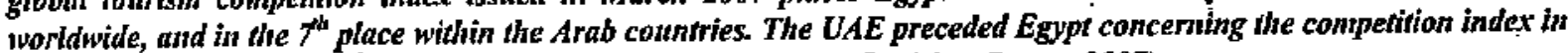
which the UAE was the $18^{\text {th }}$ worldwide (Information and Supporr Decision Centre, 2007).

Both UAE and Egypt are located in the Middle East. They have several common circumstances; both are Arab countries, Istant is the official religion, clase cultrere, etc.... Therefore, Dubai represents an interesting and useful example of a successful cxperience in tourism development and subsequenty merits an examination. This study describes the experience of development of this destination and is underbing dynamics within the context of factors that are critical to destination developntent, and barriess obstructing such a process. The analysis of this experience will be useful to access and subsequenty optimize the Egyption tourism development experience.
\end{abstract}

Destination development

Different factors in the tourism destination affect tourism development significantly. Critical influences relate to accessibility (Prideaux, 2000), attraction and amenity standards (Gunn, 2004), awareness and positive images (Johns and Mattson, 2005) associated with promotion and markcting (Buhalis, 2000), a supportive government (Weaver anc :awton, 2002) and a peaceful and stable environment (Poirier, 1997).

The relative significance of each dimension is a matter for debate and partly depends on the tourist market and chatacteristics of the destinations. The contribution of attractions should perhaps be hightighted as the 'energizing power unit of the tourist system' (Gunn, 2004,), although conceptions are constantly changing with the emergence of new styles that are less geographically dependent and essentially artificial (Fyall et al, 2003).

The aim of this research is to optimize the Egyptian tourism devclopment experience through describing Dubai's tourism development experience and its underlying dynamics within the context of factors that are critical to destination development and weaknesses obstucting such a process. The analysis of this experience will be useful to access this experience and subsequently focus on the bartiers and challenges of tourism development in Egypt.

This study will be described as follows: the first section presents an overview of tourism in the Middle East, UAE and Egypt. Section 2 will describe factors critical to destination development. Challenges for the future will be discussed in section 3. In section 4, differentiation between tourism in Egypt and UAE will be provided, Choice of policies and strategies will be described in section 5. Finally, section 6 will conclude.

1- Aл overview of tourism in the Middie East, the $\mathrm{UAB}$ and Egypt

The Middle East is defined by the world tourism organization (WTO) as comprising Bahrain, Egypt, Iraq, Jordan, Kuwait, Lebanon, Libya, Oman, Palestine, Qgatar,
Saudi Arabia, Syria, the UAE and Yemen, with Israel placed in the east Mediterranean Europe category (WTO, 2005). Woridwide, in 2006, the Middle East travel and tourism economy was ranked the ninth in tems of absolute size (US\$150 billion) and is expected to grow to US\$280 billion by 2020 (WTTC, 2007; Hussain 2007a). The region recorded only $4.6 \%$ of the world's total arrivals and $3.4 \%$ of receipts in 2004 (WTO, 2005). These figures confirm the view that it is one of the least developed tourism regions in the world (Sharpley, 2002, p.221), with proposed reasons such as infrastructure's inadequacy and lack of planning and marketing (Mintel, 2002) as well as political instability. In addition to some restrictive entry procecures imposed by some countries, deeming hedonistic wcsternized international tourism unacceptable and incompatible with the Islamic region and traditions (Burton, 1995; Henderson, 2003). Global futures and foresight expect the investment in tourism and infrastructure for the Middle East to be about US\$3 trillion by 2020, with current investments standing at US\$1 trillion which is much higher than what considered global expenditure (Hussain, 2007a).

More specifically, the region is not normally associated with the leisure/holiday tourism market. That is, with the exception of Egypt, which in 1999 accounted for over a quarter of the region's arrivals, tourism to and within the Middle East has been dominated by business travel (Wahab, 2000). Nevertheless, recent years have witnessed efforts by a number of Middle East countries to develop non-business tourism in order to diversify their economies.

The region is not a uniform entity and there are variations in stances on and stages of tourism development as well as divergences with regard to domestic, regional and international tourism flows. Saudi Arabia has traditionally drawn the largest share of Middle East arrivals, $24.4 \%$ in 2004 , although its predominance is due to mass pilgrimage travel by Muslims. Egypt, as one of the principal destinations, has a long history of tourism, founded on a wel! known cultural heritage, and cannot easily be compared with 
emerging destinations offering modern urban centers and desert environments. Bahrain also represents one of the principal destinations in the Middle East, with 3 - million tourists in 2003 (WTO, 2005b). Jordan received over 1.3 million tourists, although mostly from other Middle East countries, accounting for $7.6 \%$ of the regional total. However, tourism has become the main stay of the Jordanian economy, contributing up to $26 \%$ of GDP, whereas for other countries, such as Libya, Yemen, Syria and Saudi Arabia, tourism is much less economically significant. Some countries in the region have a larger supply of cuitural and natural attractions (e.g. Yemen, Syria, Iraq and Libya) and, hence greater opportunities for tourism development. However, for political, cultural or economic reasons, these countries have been less willing or able to exploit their potential although they have a greater economic need to develop tourism (Henderson, 2006).

Conversely, the Arabian Gulf countries possess fewer attractions and, perhaps, are not conventionally viewed as possessing. tourism potential or, indeed, neecing tourism as an economic sector. However, they have increasingly sought to diversify and strengthen their economies.

The driving foree behind economic diversification in the Gulf Stales has been the fluctuations in global oil prices and the uncertain future for their petroleum-based economies. These countries moved towards diversification, privatization, deregulation and liberalization of foreign investment rules. These policies bave been beneficial to the tourism industry. which is also recognized as a worthwhile option by non-oi] producers. Lebanon, for example, notwithstanding former and recurring troubles, is tuming to tourism to assist econounic recovery (Reuters, 2004).

The outlook of tourism depends heavily on the degree of peace and security actually existing. Inbound extra regional tourists have been discouraged by political instability and fears of global tetrorism (Aziz, 1995; Kelly, 1998; EIU, 2003a). In addition. to severe and rude procedures from foreign destinations towards Arab tourists mainly äfter September eleventh and the bad image of Arabs and Muslims in Foreign countries were expected to cause an ongoing trend towards an intra-Arab travel

- UAE lies in the heart of the Middle East and is one of the world's fastest growing economies with a per capita jncome of US $\$ 31,000$ (IMD, 2005). According to the global touristn competitiveness reports by the Worid Economic Forum, UAE ranks $18^{\text {th }}$ the whale world and number one in the Arab world, (Information and Decision Support Centre, 2007 and Rahman, 2007a, b). It is known as the $4^{\text {th }}$ best for conventions and $3^{\text {rd }}$ best for business, but still does not feature in the top ten country brands (Future brands, 2006).

The UAE has witnessed great efforts to build tourisin infrastructure and market its attractions (EJU, 1993). However, tourism development has not been uniform across the UAE, and although for political and economic purposes the UAE is considered a single-nation state, there is no planning, co-ordination and marketing of tourism at the national level. Thus, it has been left up to the individual emirates to develop their own tourism sectors and, as a resuli, some of the emirates are; in effect, conpeting with each other for a share of similar markets (Sharpley, 2002).

Dubai is one of the seven autonomous sheikhdoms making up the federation. Other members are Abu Dhabi, Sharjah, Ras-Elkhaima, Ajman, Fujairah and Umm al-Qaiwain. These vary considerably in size and population, but all have undergone modernization and urbanization (Clements, 1998). Dubai and Abi Dhabi are the main economic contribulors out of the seven emirates that make up the UAE. Nón-oil revenues contribute to $63 \%$ of the GDP (UAE Interact, 2007a). Dubai occupies a land area of $3900 \mathrm{~km}^{2}$ and is the second largest emirate after $A b u$ Dhabi. Both have international aiports, as does Sharjah, and several tourist attractions like beaches, cities, oases, mountain and desert landscapes and peoples, ancient civilizations and nature reserves (UAE, 2005).

Abu Dhabi's economic growth and development has been underpinned by the production and export of oil and peiroleumi .based products. Nevertheless, in common with other oil-producing states in the region, Abu Dhabi has, over the past decade, been seeking to diversify its economy in order to reduce its dependence on oil. Most recently, attention has been foused on developing tourism. Abu Dhabi possesses a yariety of natural and cuitural attractions, along with infrastructure, good communications and a relatively small yet "high" qụ̈lity accommodation sector, which collectively represent a sollid foundation for the development of tourism. Furthermore, it is safe, clean and relatively liberal and enjoys political stability. Thus, it would appear that, at first sight, Abu Dhabi is well placed to exploit the opportunities offered by tourisin. Nevertheless, Dubai will remain the dominant tourism destination in the Gulf region; indeed, it is the only emirate to collect and provide tourism statistics to the WTO and, as such, is synonymous with the tourisin in the UAE (Sharpley, 2002).

Abu Dhabi contributes $59 \%$ to the GDP of UAE $(56 \%$ is oil dependent) while Dubai contribules $29 \%$ ( $5 \%$ is oil dependent). Dubai contributes over $80 \%$ of the non oil assets (Middle East Monitor, 2007). Tourism curretitly contributes $18 \%$ to Dubai's GDP directly and $29 \%$ indirectly (AI Hakeem, 2007).

Dubat is considered one of the fastest growing destinations workdwide (EIU, 2003b). If attracted 5.8 million tourists in 2003 (WTO, 2005b). In 2006, 6.5 million people visited the Emirates excluding visilors siaying with friends and relatives (Rahman, 2007b). Guests at hoteis and hotel apartments in 2002 were primarily from other Gulf Cooperation council members (34\%), South Asia (25\%), other Arab states (16\%), Europe (15\%) and Africa ( $9 \%$ ) (DTCM, 2004a). According to DTCM's (2007) One Stop Information Center, though hotel occupancy has inereased from $66.8 \%$ (in 1999) to $82 \%$ (in 2007); the average length of stay for hotel guests have not increased siguificantly $(2.5$ nights in 1999 to 2.7 niglits in 2007), hence, Dubai is not considered a long-stop vacation. But earnings from tourism cxceeded US\$1 billion and surpassed oil revenues that year to directly and indirectly account for $17 \%$ and $28 \%$ of GDP respectively. Business, conference and exhibition travel are lucrative markets, but leisure was the main motive for $75 \%$ of visits to Dubai in 2003 (DTCM, 2004a).

Egypt has winnessed a significant growth in tourist arrivals. The total number of antivals reached more than 9 million tourists in 2006 (Minjistry of 'Tourism, 2007). The average tourist nights have increased fiom 8.9 nights in the period (Jamuary-March 2007) to 10 nights during the same period in 2008. This fits wi1h the tourism development ptan which targets to increase the average tourist nights and subsequently incrcase the average expenditure through diversifying the tourisnt product and the effective exploitation of the tourisn attractions. The total tourism revenues reach 8.18 billion $\mathrm{S}$ in fingncial year $2006 / 2007$ with an increase of $13 \%$ compared with 2005/2006 (Ministry of Tourism, 2008). The total tourism revenues reach 2.6 billion US\$ in the period (January- March 2008) (Central Bank of Egypt, 2008). These figures make tourism a fundamental source of income for hard currency in Ëgypt.

Although Egypt precedes UAE in tems of total number of arrivals and length of stay, but we cannot compare these 
numbers absolutely. Considering these numbers proportionally with the population's size, and the attraction's variety and quanlity, UAE performance will surpass Egyp1 performance and the comparison will not be to the advantage of Egypt.

2- Factors critical to destination development (strengths and opportunities)

It is evident that Egypt and UAE are ranked the top tourism countries in the Middle East and they are in a position 10 develop Iourisin, although a nutnber of challenges must be overeome if opportunilies are to be fully exploited. The following section will describe strengths and opportunities found in both destinations. The description focuses more on Dubai to examine its experience in order to put our hands on its key of suceess.

2-1- Stability Stability in economics, social and political domains is cssential for tourism as severe disturbance and volatility will deter many tourists, investors and the industry of tour operators and travel agents. Income from oil in $\mathrm{UAE}$ provides all the emirates with a standard of living and degree of security. From the politieal side, there has been an uninterrupted period of political order and continuity, alongside economic prosperity, if litlle democracy as otler A rab countries (Itenderson, 2006).

Dubai is second in political and financial power to Abu Dhabi and exercises a degree of independence and autonomy in econonic policy making (EIU, 2005a). Dubai acts as a regional depot and promotes itself as the commercial and the financial nexus of the gulf. The relativcly free market econony now incorporates trade and services (Ministry of Planning, 2002).

Dubai is seen as a comparatively liberal and cosmopolitan society, with little threat of civil unrest and low crime rates. and expatriates make up about $82 \%$ of the 1.4 million population. $85 \%$ of the population is employed (Dubai Healthcare City, 2007). It is a Muslim statc yet the practice of other religions besides Islam is permitted and there is a degree of openness to outside influences rurely observable in much of the Middle East (BBC, 2004 and FCO, 2004).

Services contribute $74 \%$ to Dubai's GDP (Balakrishnan, 2007). Therefore, one of the areas Dubai strategic plan focuses on its people management. Services currently account for $85 \%$ of the employment of nationals who are less than $2 \%$ of the workforce. A key driver is Emiratisation where the emphasis is to balance demographics and responsibility, reinforce culture and knowledge nanagement through a quota system for nationals.

Dubai embraces the latest technology and is currently integrating services of all 24 government officials (Balakrishnan, 2008).

Egypt now witnesses a relatively stable econonic and political environment compared with previous periods after successful efforts that have been given to control terrorism.

Egypt has lately become an attractive investment option, due to the encouraging policies adopted by the government and the improvement of the investment environment in general. The real domestic product growih rate reached $7.5 \%$ in Jantary-March 2008, and the executive investment increased by $38.9 \%$ to reach 57.1 billion Egyptian pounds compared with the sane period in 2007. Moreover, tourism investments in 2006/2007 amounted to LE 13 billion, of which $83.5 \%$ were private sector investments. Although macroeconomic indicators have been relatively positive in the last years, income distribution has been poor. On the other hand, the average income per person became 10058.5 L.E. (aboul 1828US\$) in 2006/2007 and is expected to be 11741 L.E. (about 2134USS) in 2007/2008. However, the annual inflation rate increased by $19.7 \%$ in May 2008 versus $10 \%$ in the same month in 2007 (Ministry of Economic Development, 2008).

2-2- Government tourism policy Governments have a crucial part to play in initiating and sustaining development. The UAE government intervened and began to spend on infrastnucture (Balasubramanian, 1992 and 1993), especially in Abu Dhabj and Dubai.

the federation policy encouraged economic diversification due to fall in oil production as it is estmmated that oil will exhaust itself in 20 years (Middle East Monitor, 2007). This fact is realized in the government vision as outlined in the 2015 strategic plan. Dubai started to invest substantially in tourism which was soon the pole of the economy (Crookston, 1998)

Tourism was located at the center of the diversification programmed alongside construction, telecommunications, media, real estate and financial trading. There was thus a strong shift towards services (EIU, 2005a). Projects have been completed in a rapid pace (Balakrishnan, 2008).

The department of Tourism and Commercial Marketing (DTCM) was established in 1989 and is responsible for tourism planning, development and marketing. External consultants and internal advisors have been employed in preparing the guiding strategies and the department has a vision of Dubai as the 'leading tourism destination and commercial hub in the world'. Its mission encompasses tourism sustainability and economic growth, industry partnerships, unique experiences for visitors and innovation in promotion (DTCM, 2004c). The intention is to host 15 million international tourists by 2010 and 40 million by 2015 (DTCM, 2004d). The World Travel and Tourism Councit (WTTC) predict the UAE travel and tourism will grow at $5 \%$ (2007-2016), which is higher than the Middle East average of $4.4 \%$ and the world average of $4 \%$. UAE travel and tourism industry attracts one in every 8.5 jobs whereas the world average is one in every 11.5 jobs (Rahman, 2007b). The rapid pace of development in Dubai was initially fueled by oil but today this forms less than $6 \%$ of the overalt GDP (Molavi, 2007).

The first and foremost advantage for Dubai is its leadership wilich is strong and endowed with great vision. They have constantly taken advantage of the strategic location and been proactive to giobal change.

Dubai as of 2005 had a GDP of US\$37 billion with a per capita income of US\$31,000. The 2015 vision is to increase GDP to US\$108 billion and GDP per capita to US\$44,000. However, the economic welfare of residents need not equale to nationals who form a shrinking minority. The median income of its.average expatriate citizen is less than US $\$ 700$ (Gulf News, 2007a).

Morcover, Dubai has been able to. attract foreign direct investments (FDI) through incentives like no tax, free zones and the revised property owncrship laws. The World Competitive Yearbook ranks Dubai $5^{\text {th }}$ in terms of positive image abroad with respect to encouraging business development (IMF, 2005).

With the booming econony, inflation is an issue as the Dirham is pegged to the Dollar. As of May 2007, the US dollar was devaluing compared to the Euro. This was in favor of European investors (Baik, 2007).

The Egyptian government gives interest to the infrastructure and the hunian deveiopment where $85.5 \%$ of the general investments are directed to support these factors specially providing clean drinking water and enhancing human developinent efforts (education, health ...). The Egyptian share in the capital for the investment companies hes increased from $71 \%$ in the period (January- March 2007) to $75 \%$ in the same period in 2008 . Conversely, the Arab share las decreased in the period (January-March 2008) 
compared with the same period in 2007. The direct foreign investment flow continues to increase to reach 4.8 billion dollar in the period (October- December 2007), and this reflects the enhancement of the investment climate in Egypt (The General Investment and Free Zone Authority, 2008). The executive investments in the tourism sector have increased significantly in 2005/2006 with a proportion of $25 \%$ compared with year 2004/2005. The tourism share is $39.2 \%$ from the services' export for Egypt in 2006/2007 (Information and Decision Support Centre, 2008). The number of companies working in the infornation technology and communication sector reached 2435 companies till March 2008 (Ministry of Communication and Information Technology, 2008).

Egypt starts a program to raise the Egyptian tourism within the period (2006-201I). The government is targeting 14 million foreign arrivals by 2011/2012 and to attract investments with a value of 8 billion LE from the private sector (Ministry of Tourism, 2008). To achieve this target, the govemment is massively expanding its tourism facilities, as well as modernizing its supporting infrastructure. The Egyptians authorities also aim to attract private investment to the area to fund the expansion plans, offering overseas investors a potentially lucrative entry route into a growing tourist sector.

\section{2-3-Accessibility}

Dubai is very strategically placed. It lies at the confluence of the Middle East, Asia, Western Africa and Central/Eastern Europe. It aims to be an air transport hub for the Middle East and the Far East and authorities are building an appropriate communications infrastructure. The airport has 28.7 million passengers transiting per annum according to the Airports Council"s International Report (Rahman, 2007a). A US\$4.1 billion upgrading is underway which will enable the airport to hancle 40 million passengers by 2010 and 100 miltion by 2025 (Matthews. 2003). A new international airport being buiti will handle 120 million passengers and 12 million tons of cargo (Balakrishnan, 2008). The Emirates airline has seen significant growth. Today, Emirates is the $4^{\text {th }}$ largest airline in the world (in terms of passenger traffic) (Emirates airline, 2007). Dubai's open sky policies and facilities bave encouraged over 112 airlines to connect via Dubaj to more than 165 destinations (Emirates airline, 2007). Its association with FIFA as the principal sponsor has helped change the image of Dubai. Emirates airline is perceived as a global carrier (Anastasiou, 2007). Dubai also markets itself as a cruișing hub (Peisley, 2000).

Accessibility can extend to issues of costs of visiting. Value for money' may be as important as prices. Dubai has marketed itself in western markets as an exotic, but safe, beach tourism location with diversions of shopping and assorted cultural and natural heritage attractions. Tluus, it has many longer established competitors such as Australia, the Caribbean, Malaysia, the Maldives, Mauritius, the Seychelles, South Africa, the Canary Islands, Thailand and Turkey. A comparative study concludes that a standard package holiday in Dubai is priced slightly below average; but that the Canary Islands, Egypt, India, Jordan. Malaysia, Morocco, Qatar, Thailand, Tunisia and Turkey are more price competitive (DTCM, 2004a).

Egypt possesses 20 airports (Ministry of Civil Aviation, 2006). Cajro intemational airport is the primary hub for Star Alliance member Egypt Airr. It's the second busiest airport in Africa. It handled just over 125000 aircraft departures in 2007. 58 airlines use Carro intemational airport (including charter airlines) and 10 cargo airlines. With the assimilation of Egypt Air into Star Alliance in July 2008 the airport has the potential to be a major hub. In 2007, the airport served $12,577,524$ passengers ( $+16.7 \%$ vs. 2006$)$. A luxury 350 rooms five star hotel is planned to be open in 2010 as a part of the terminal (with a direct connection to the building). Expanding the Cairo metro to serve the aimport (an advanced stage of planning) is expected to be operated by 2010 . Furthermore, an automated inter-terninal train transport system connecting all three passenger tenninals is planned to be operated (Cairo Intemational Airport, 2008). However, in spite of this interest and efforts, the airport's services and the congestion are still a dissatisfactory factor for tourists visiting Egypt.

The information and conmunication technology sector have witnessed different developments such as "Egypt connectively", "while in Egypt still connected" and "Epayment network developments" (Ministry of Communication and Information Teclunology, 2008).

Conceming Cost of visit, Egypt prices are incompatible as it is considered a cheap destination compared with other destinations.

\section{2-4- Amenities}

The most important amenity demanded by all tourists is accommodation and, again, hotel construction in Dubai has been offictally encouraged. There are approximately 285 hotels and 135 service apartment blocks according to DTCM in 2006 (Rahman, 2007a). Hospitality development has been facilitated by a relaxation of nules on land leasing and ownership and a large number of star properties will be opening within the next few years, amongst them a 'hydropolis hotel' built to a depth of $20 \mathrm{~m}$ underwater (DTCM,-2005).

Much of the commercial interest has been in the luxury segment and the striking Burj AlArab beach side hotel which is something of a tourist icon of Dubai. Another well publicized project is the Palm, two palm-shaped man made islands, which have required financing of over US\$3 billion. They added $120 \mathrm{Km}$ to Dubai's shoreline and house 48 hotels, 2000 residential plots and additional amenities. An equally expensive development is that of The World, a collection of 250 themed artificial islands fashioned after the five continents, which will comprise accommodation and leisure services (Hotels, 2004). Nakhcel (a part of Dubai world). is one of the world's largest privately held real estate developers. It takes credit for planuing over $1,000 \mathrm{~km}$ of coastline through its palm trilogy, world and waterfont projects and will develop over 2 billion square feet of land (Balakrishnan, 2008). It is expected to coltribute $25 \%$ to Dubai's tourism GDP (Nakheel Advertisement, 2007). Plans for the Burj Dubaj (Dubaj tower), touted as the highest ever building, were also made public in 2003 and one of its hotels will be the Dubai Armani Hotel, a partnership between the fashion designer and a Dubai property developer (The Financial Times, 2004). The accommodation in Dubai is luxurious and unique. They represent a principal attraction.

In Egypt, the number of hotels and the tourism resorts reached 1309 hotel establishments in 2006 and 585 hotel establishments are under construction. There had been a significant growth in the number of travel agencies with a rate of $58.6 \%$ from $84 !$ companies in 1997 to 1334 companies in 2006. The occupancy rates was unstable in the period 1997-2006 where in 2000 the occupancy rate reaches $73 \%$ although the lowest occupancy rate was in 1998 as it reached $45 \%$. The last few years had witnessed a decreasing direction in the occupancy rate as it decreased with $5 \%$ in 2006 compared with 2005 (Ministry of Tourism, 2006).

\section{2-5-Attractions}


A5 mentioned, Dubai's attractions center on its $64 \mathrm{~km}$ coastline and resort hotels, which boast facilities for sailing, water skiing, windsurfing, diving, fishing, golfing on grass or sand courses and bird watching. Future sports attractions range from cricket, football, fonmula one racing. Moreover, the development of the "Sports City" makes it an ideal venuc for future Olympics. The desert represents another type of attraction for tourists. Falconty and camel racing are other amusements. The city has extensive shopping opportunities, with retailing a prominent component of new mixed developments, and a few sites of built lieritage (Henderson, 2006).
The great interest of oflicials and developers is in accommodation projects and attractions such as the US\$S billion Dubailand theme park. Dubailand will also host the bawadi- a hotel stripes similar to Las Vegas and the world's larges! Ski Doine which will attract an additional 200000 visitors per day (IIussain, 2007b). In another illustration, Ski Dubai opened in 2005 within the Mall of Emirates, reportedly is the largest shopping space outside of the USA, and sells skiing and snow related pursuits in a 'winter wonderland' of sub-zero temperatures (The Observer, 2005). Many of Dubai's attractions are superlatives

Table 1: Some of Dubai's superlatives

\begin{tabular}{|l|l|}
\hline Media proclained 7 stars hotel & Burj Al Arab \\
\hline The World's highest hotel & The Burj al Alum \\
\hline The World's largest hotel & Asia-Asia \\
\hline The World's first underwater botel & Hyöropolis \\
\hline World tallest building & The Burj \\
\hline The World's largest waterfront development & Dubai Waterfront \\
\hline The World's largest mall & Mall of Arabia \\
\hline The World's largest anusement park & Dubailand of which Universal studios is a part \\
\hline The world's largest airport & Jebel Ali at Dubai World Central \\
\hline World's first purpose- built sport city & Dubai Sport cily \\
\hline Region's largest logistic bub & Dubai World Central \\
\hline
\end{tabular}

(Source: Balakrishren, (2008)

According to the 2006 Global Retailer Development Index, UAE ranks $16^{\text {th }}$ with respect to Gross Leasable Area (GLA). Average daily private consumption spending in $U A E$ is at US\$26.8 making it the highest in the Arab world where others spend an average of US\$3.50 on consumer items (Kawach, 2004). People spend over US\$700 billion per annum in the Dubai Duty Free alone, which is the largest in terms of turnover next to Healtrow (London) and Incheon (Korea) (Retail ME, 2006a, b). In 2006, the average spent of Dubai visitors amounted to AED 6,429 per day (Ditcham, 2007).

With the intention of broadening Dubai's attractions base, the DTCM's Environmental Tourison Task Force is exploring ccotourism possibilities. The $6.2 \mathrm{~km}^{2}$ Ras Al-Khor Wildlife Sanctuary at the head of the Dubai Creek marks the beginning of the programme and other sanctuaries are to be designated (Gulf News, 2004c).

Medical tourism exceeds US\$56 billion worldwide in 2006 and is growing at $15 \%$ pa according to a report by the Abu Dhabi Chamber of Commerce and industry (A1 Deen, 2007). Within the UAE it is expected 10 generate AED 7 billion by 2010. The focis is to attract 6 million of the 600 million tourists with special needs and get residents to use medical facilities within the Emirate rather than going abroad. Education is another area of lourism. The government announced an AED 37 billion find for education and knowledge developnent in the region (Zawya, 2007).

Events are presented and packaged as attractions, many of these are organized during the hottest summer months, which are the pcak season. Such events put Dubaj in the media spotlight globally and are a tool with which to combat seasonality and convey nations of a superior quality destimation in the case of prestigious sporting context Among these events are the Dubai Summer Surprise and the Dubai Shopping Festival which attracted more than 3.6 million tourist in 2006 contributing $8 \%$ to the overall GDP (Gulf News, 2007c).

The meetings, incentives, conferences and exhibitions (MICE),as a segment of business tourisin is expanding rapidly from both a demand and supply perspective (Dwyer and Forsyth, 1997). Although statistics are limited, the evidence suggesis that ever increasing numbers of cities globally are investing in conference facilities, with growth particularly evident in the Asia Pacific fuelled by economic growth in that region (Mugbil, 1997). Furthennore, the conference and exhibition market represcnts an opportunity to increase occupancy in hotels during low tourism seasons. Egypt faces stiff competition in this market from Dubai (which hosts over 50 exhibitions annually) and other centers in the region (Dew, 2000 ), and it has been observed that considerable oversupply of MICE facilities occurted recently. Therefore, for Egypt not only will greater promolion efforts 'be required to attract clients, but also more integration will be required between, for example, the General Exhibition Corporation(authority), the Egyptian Chamber of Commerce, hoteliers and other stakcholders in order to promote and provide a wider range of facilities and events under the MICE umbrella.

Egypt possesses a rich array of natural and cultural assets; it has unique attractions which characterize it compared with other destinations. The cultural/heritage attractions vary from Pharaonic, Greco-Roman, Coptic, Islanic, recent and contemporary attractions. Egypt enjoys fascinating beaches cxtending for $3000 \mathrm{~km}$. The Mediterranean coast and the red sea coast offer facilities for sailing, water skïng, parasailing. windsurfing, diving and fishing. The environment attractions (oases, protected arcas, descrts, lakes...) are potential of successtul environment and therapeutic tourism. Thus it is a well known destination which possesses a long history of tourism. It cannol be easily compared with emerging destinations offering modern urban centers. Moreover, Egypt also enjoys good weather all year around. It is a year round destination (Destinations in Egypt, 2008).

New tourism niche areas such as sports tourism, health and therapeutic tourism, shopping tourisin, safari and residential tourism have evolved as a result of ongoing efforts to upgrade the quality of the sector.

Recent development in tourism includes several Megatouristic projects such as Cairo festival cities, Mediicrranean projects such as Marassi, Almaza bay resort and Porto Marina and Red sea projects such as Gamsha bay, Serrenia, Port Ghalib, Madinat Makadi and Porto Sokbna. These Mega projects' will ameliorate recreational tourism by offering various and different attractions (Am Cham Egypt, 2008). 


\section{2-7- Promotion}

Promotion in Dubai is coordinated by the DTCM, working with a network of 14 overseas offices, and has intensified over the past 5 years. The rise in international tour operators and travel agents frorn the world's leading generators selling Dubai, from 258 in 1996 to 2265 in 2002 , is quoted to demonstrate the success of its campaigns (DTCM, 2004a).

Dubai's attractions and amenities, as well as conventional image of suл and sand place are facets of the destination brand communicated in a marketing exercise (Gulf News, 2002 and DTCM, 2000). Although Islamic and Arab culture is clear, Dubai's tolerance and cosmopolitanism ane stressed.

It is estimated that in order to promote the "Dubaj" brand, the Department of Tourisin and Commerce unofficial marketing budgets are to exceed US\$32 million. However, if the projected spend of quasi-govemment organizations are added, the amount will exceed US\$275 billion for the year 2010 (UAE Interact, 2007b).

Egypt has witnessed recently an integrated marketing strategy as the global advertising campaign, domestic advertising campaign as well as EU program for tourism. advertising and nurketing. It gives interests to promote different types of tourism in Egypt to attract a wider range of tourists. The importance of using recent tourism marketing tools is stressed by officials. These tools must focus on the technological changes occurred in the principal tourism natkets (Elezaby, 2008b).

Different tools are used to promote Egyptian tourism as an example, the Exhibition for the drown monuments which had been established in Paris helps to promote the Egyptian tourist product (Elmasry- Elyourn, 2007).

The budget of Egypt marketing budget is linited compared with that of UAE. The cost of the Egyptian tourism promotion campaign "within the Arab world" is US\$3 million (Elezaby, 2008a).

\section{3- Challenges for the future}

Several obstacles are facing Egypt's and Dubai's tourism development, yet must be scaled if the momentum is to be maintained and targets reached. There are even some doubts about whether such attainment is desirable given possible adverse impacts, which could, represent further hurdles to sustainable long tem growth. Some challenges for the future will be discussed in the following sections followed by summary and analysis of strengths, weaknesses, opportunities and threats (SWOT analysis) of the tourism development in both countries.

\section{3-1-Stability and gavernment tourism policy}

History of the Middle East region has always been distorted and September cleventh 2001 made things worse. Moreover; the instability in Iraq could have also negatively affected tourism in Egypl and Dubai.

As we mentioned before Dubai is a commercial center and therefore it could be affected by any sudden change in both the international and regional economies. It is not actual destination circumstances that are of relevance, but popular perceptions of these concems about tourist security and the terrorist risk have mounted globally after September eleventh 2001, The UAE has not been yet a victim of attack by Islamic extremists, but still'there is always a risk to be attacked by terrorism which will cause damage in touris!n and economics. Conversely, Egypt has suffered from the terrorist attacks although it was safe in the last few years but the risk to be attacked again by tertorism is stilt probable.

Although, Dubai tourism is regional which may be less influenced by these threats than westem tourisin, this is not the case for Egypt; yet the regional tourism represents a signifieant proportion in tourism in Egypt, but the great proportion of tourists are from European countries which are very sensitive to any threals.

In Dubai, there is a great govemmental interest in tourism. However, there are opportunity costs and financial risks associated with the approach it has adopted and economists might criticize the amount of capital spending on such unpredictable industry as tourism. The net profit from tourism should be calculated to assess the economic benefit of this industry.

Tourism is also partly responsible for the unprecedented constnuction underway in Dubai and real estate has been substantial investment, leading to some fears of an economic 'bubble' and the repercussions should it burst. (DTCM, 2005).

A big caution area for Dubai is the rapid pace of development which may not give sufficient time to leam from mistakcs as problems arise when development is rushed with little considerations for the environment (May, 1991).

Ecotourism promotion could seriously ham wildlife and vegetation, Population growth and tourism industry operations are augmenting pressure on the coastline escalating erosion and pollution and more tourists will exacerbate stresses on urban, coastal and desert areas. The original vistas of sandy beaches and open view of the sea have been dramatically modified. Legislation has been passed in an endeavor to safeguard protected zones (Gulf News, 2004d), but its effectiveness has yet to be tested (Pos et al., 2000). Moreover, there is the atmospheric pollution and the congestion in traffic which may be wortl when all real estate properties will be occupied (EJU, 2005b). The airport is close to the city center which makes it a source of noise and aircraft engine emissions aredeleterious to air quality. Such environmental degeneration renders.transport planning more urgent (Henderson, 2006).

Another potential challenge is that $82 \%$ of Dubai's population is expatriates. Nationals control sizeable assets and have a huge unemployment rate. With a service dependent economy, people play a very important role in the perception of service satisfaction. A majority of the cheap labor is male and they live without their lamilies; this makes for much skewed demographics. Therefore maintaining security when tourists will outnumber residents by $4: 1$ is an area of worry (Balakrishnan, 2008).

Moreover, balancing the Arab traditional laws with intenational are another challenge facing both destinations especially Dubai as locals are not used to being opened to other cultures.

As a result of Dubai's success- each emirate has been replicating the real estate and free trade zone formula which reduces differentiation and causes confusion as the distances between emirates is smalt. It is estimated that in this region over US\$1,200 bitlion worth of real estate projects are under development with US\$600 billion in UAE, $50 \%$ of which is Dubai's (Hussain, 2007a,b).

The financial crisis which stared in August 2008 has a serious impact on the econoric growth of almost all the countries of the world. Although, the forecasts of the magnitude and duration of the crisis may vary, its impact on the incoming tourism is sure. The financial crisis will affect the GDP of most of the generating countries which will directly infuence the decisions of their citizens for oulbound tourism. This crisis will also have an impact on the devaluation of the curencies. Moreover, the decrease in oil prices may also affect tourism as it will cause a decrease in the income of the oil producing countries which constitutc a principal market for intemational tourism of both Egypt and Dubai.

For all destination countries the intemational tourisn markets are beyond their own boundaries. Therefore, the real and potential tourism demand outside relies not only on the 
social and economic development of the tourist generating countries (demand side), on the entire world political and economic situation, but also on the political and economic relationship between the tourist generating countries and the receiving countries. This point stresses the inportance of economic and political cooperation and agreements between destinations and the tourist geterating countries (Zhang et al. 2000).

The great challenge for Egypt is to encourage and be able to attract foreign direct investment. Egypt is still a developing country with limited budget; therefore it needs great anount of foreign exchange to import foreign technology, equipments and inaterials, and to introduce personnel and management for the couniry's modernization. Moreover, it needs budgets to be able to accomplish many of the planned projects needed to enhance the infrastructure and tourism development.

3-2- Accessibility and amenities

Aircraft technology and the introduction of planes that can fly extended journeys without refueling stops constitute a threat for Dubai as an anticipating boom in inbound air traffic. Moreover, other airports are competing with Dubai as a transit for long haul travel between Asia and Europe. The stopover tourism matket too has its drawbacks owing to the brevity of visils and effort has to be expended on prolonging the duration of stay in order to maximize earnings.

Another problem faces Dubai as a cruising hub, partly because of the home narket's small size. As a result of the hot weather, the tenninal is not utilized during the suminer: It tends to be excluded from itineraries. Negative images of the wider Gulf region and management worries about having to cancel programmes because of unrest have also deterted American and Europeans companies from sailing in its waters and berthing ships in Dubai (Peisly, 2000).

Conceming the accommodation, the hotel overbuilding and the dependence on supply-indueed demand have been criticized. The occupaney rate was $81.1 \%$ in 2004 (EIU, $2005 \mathrm{c}$ ), but hotel overbuilding may cause a decrease in occupancy rates if the expected number of arivals fail to reach the expected levels (Greene and O'Loughlin, 1999). The interest is in the luxury hotels segment which may lead to the neglect to tourists with more modest budgets, whose spending in other areas is important. Publicity overseas about the. projects made reference to earlier may also reinforec totions of Dubai as an expensive destination and price competitiveness in general becomes a matter of concem, with evidence of some current dissatisfaction over prices and value of moncy (DTCM, 2004a).

In spite of the government's increasing efforts to enhance services, infrastructure, and human resources, still Egypt suffers shortage in inftastructure and service facihties as well as transportation means. It also suffers from unreliable product quality.

Arother challenge" is the contradictions between mature tourists and premature market's mechanism. Egypt's international tourism is still not able to shake of the shackles of the system in terms of organizations and methods of operations and management.

\section{3-3- Attractions and promotion}

Dubai's cultural and natural heritage aftractions ate limited compared with other destinations. Certain existing and planned leisure facilities such as shopping complexes and theme parks have a sterility and homogeneity, of which tourists may tire once the novelty has abated. Moreover, the ubiquitous building sites are an unattractive feature of the cityscape and the fierce summer heat is debilitating and restricts activity (Balakrishnan, 2008).

In the long run, the developinent of other man-made attractions in other destinations will lead to the loss of Dubai's differentiations. When building destination images, it is better to build it on the promise of something more tangible and concrete than a passing title. Efforts should be oriented to improve and upgrade the natural tourist attractions to avoid simple imitation and duplication of attractions of the same kind. Moreover, there is no single logo or symbol representing Dubai (Balakrishnan, 2008). There is an official awareness of these weaknesses and DTCM is aiming to add variety to Dubai's attractions, encourage longer stays and offset the seasonality effects (DTCM, 2000).

However, Crookston (1998) warns of potential impediments to sympathetic conservation caused by an enthusiastic and intervening government that is accustomed to excessively spending on futuristic projects. Domestic architecture has given way to international style skyscrapers housing office blocks, hotels and retail malls, which largely ignore indigenous society and climate. Older parts of the town bave been neglected, leading to a decay and eventual clearance (Bousaa, 2003).

There is lack of access to data. Companies are reluctant to give information as are their einployees. Another caution area is the promises so heavily advertised on which the brand Dubai stands for are still being completed. This can cause disappointment in investors and tourists (Balakrishnan, 2008).

Egypt suffers also from the lack of knowledge of international markets, backward international marketing and promotion means as a result of limited marketing expenditure. This drawback may influence to some extent the image building of Egypt in the international tourism marker (Elnagar, 2008).

Globalization has led its competitors into its own territory, leaving trades that were protected to compete directly with their counterparts. Some weak links of Egypt's tourist industry such as travel agencies may meet with great difficulties. As travel agencies in Egypt are not very strong, and most of the travel services are small in size, poor in management, and they canuot match their counterparts in the developed tourism. countrics in terms of technology; capital, personnel, networking and service quality (Deebes, 2002 ).

Many Egyptians sec tourism as a quick way to earn a substantial living. Moreover, the explotation and the harassment that faces tourists in their visit to Egypt is a major threat. This negative experience can erode any other incomparable attractions and positive factors in the tourist's experience.

Today, more and more countries pay great attention to the development of tourism, seeeing it as an important way to earn moncy and improve the international balance of payments. Therefore, they promote their countries by all means leading increasingly to fierce competition among all destinations. In fact, nowadays, tourisu competition is not competition anong the tourist enterprises, but inore importantly, the competition of national power among destination countries (Zhang et al., 2000).

4- Differentiatlon analysis between Egypt and UAE

The first tourism competition index issued in March 2007 places Egypt in the $-58^{\text {th }}$ country within the 134 countries worldwide, and in the $7^{\text {th }}$ place within the Arab countries. The UAE, Israel, Tunisia, Turkey and Morocco preceded Egypt concerning the competition index in which the UAE was the $18^{\text {th }}$ worldwide, Tunisia the 32nd and Turkey and Morocco the 52 d and $57^{\text {th }}$ respectively. The total tourism competition index for Egypt risached , 4.2 points while the subsidiary tourism competition indices for each of the organizational franework, the business climate, the infrastructure and the human, cultural and natural resources reached 4.5,3.5 and 4.7 points respectively (Information and Decision Support Centre, 2007). Concerning the business climate and tourism infrastructure, the order of Egypt was delayed as it was the $85^{\text {th }}$. As for the human, culture and natural resources working 
in the tourisn field, it occupied the 69th position. The low prices are considered to be ane of the strongest points in Egypt to attract tourists, where it occupied the $5^{\text {th }}$ position conceming price competitiveness.

The UAE showed superiority with respect to all the subsidiary indices as shown in table 2 ; the organizational framework, the business climate and the infrastructure index as well as the human, cultural and natural resources. The following table shows the subsidiary and the lotal tourism competition index for some countries:

Table2: The subsidiary and the total tourism competition index for some countries.

\begin{tabular}{|c|c|c|c|c|}
\hline $\begin{array}{l}\text { The } \\
\text { country }\end{array}$ & $\begin{array}{l}\text { The toial tourism } \\
\text { competicion findex }\end{array}$ & $\begin{array}{l}\text { The organizational } \\
\text { framework index }\end{array}$ & $\begin{array}{l}\text { the business climate and the } \\
\text { infrastructure index }\end{array}$ & $\begin{array}{l}\text { the human, cultural and } \\
\text { natural resources index }\end{array}$ \\
\hline UAE & 18 & 18 & 19 & 24 \\
\hline Israel & 32 & 36 & 33 & 35 \\
\hline Tunisia & 34 & 12 & 47 & 37 \\
\hline Turkey & 52 & 53 & 63 & 48 \\
\hline Morocco & 57 & 47 & 72 & 52 \\
\hline Egypt & 58 & 50 & 85 & 69 \\
\hline India & 65 & 62 & 55 & 81 \\
\hline Algeria & $\overline{93}$ & 89 & 93 & 97 \\
\hline
\end{tabular}

(Suarce: The intenational economic fortm: the travel and fowrism contpetitiveness repost (2007)

This index used the data available in 2005-2006 from different countries. It consists of different subsidiary components which constitute the travel and tourism competitiveness. These components are:

The organizational framework:

1- Political rules and the regulations

2- Environmental organization

3- Safety and security

4- Health and cleanliness

5- Travel and tourism preference

The business climate and the infrastructure:

6- Air transportation infrastructure

7- Land transportation infrastructure

8- Tòurism infrastructure
9. Information technology and communication infrastructure

10- Prices competitiveness

The human, natural and cultural resources relative to tourism:

11- Human capital.

12- National perception of tourism

13- Natural and cultural resources

From the above discussion, many of the threats are common in both destinations although some of the weakness factors in Egypt have been surpassed in Dubai. In a very short period Dubai has accomplished stable paces in the development process. The following tables summarize all the strengths, weaknesses, opportunities and threats (SWOT analysis) of the tourism development for both experiences.

Table 3: SWOT analysis of tourism development in UAE

\begin{tabular}{|c|c|}
\hline Strengths & Weakness \\
\hline $\begin{array}{l}\text { political stability and continuity, alongside economic } \\
\text { prosperity }\end{array}$ & Hage opportunily costs and financial risk \\
\hline modem infrastructure and communications : & Instability in the Middle East \\
\hline Favorable winter climate & Hot weather in surnner \\
\hline Diffcrent attractions (many of them, world's superlatives) & Limited supply of natural/cultural allractions \\
\hline comparatively liberal and cosmopolitan society & Expensive and dissntisfaction over value of money \\
\hline Clear government vision for the ingortance of tourism & negligence of tourists wilh more modest budgets \\
\hline $\begin{array}{l}\text { Encouraging business clinale (to attract foreign direct } \\
\text { investments) }\end{array}$ & $\begin{array}{l}\text { luge unemployment rate between nationals which control } \\
\text { sizeable assets }\end{array}$ \\
\hline Safe, clean environment & Limiled statistics \\
\hline Luxurious hotels & Negative images of the wider Gulf region \\
\hline Central Iocation & Lack of manpower training \\
\hline Sufficient (unofficial) nuarketing budgets & the brevity of visits \\
\hline Established/growing conference and exhibition business & No single logo or synibol (a branding problem) \\
\hline fun and leisure centre & Majority of the population ate expatriates \\
\hline \multicolumn{2}{|l|}{ ecotourism possibilities } \\
\hline \multicolumn{2}{|l|}{ Medical tourism } \\
\hline \multicolumn{2}{|l|}{ Effective promotion campaigns } \\
\hline Opportunities & Threats \\
\hline Improve co-ordination and quality of services & Tourisin development in other slates in the region \\
\hline $\begin{array}{l}\text { Promote to relevant nhatkcls, especially MICE (Meetings, } \\
\text { Incentive, Conference, Exhibition) }\end{array}$ & Aircraft technology and other airports' competition \\
\hline Explojs culturatenvirostmxent attractions in louger terns & Fears of an econonic 'bubble' and the repercussions (burst) \\
\hline Collcet and disseminate tourisus data & Negative environment effects \\
\hline Encourage overall positive attitude towards tourismfiourists & $\begin{array}{l}\text { Certain existing and planned leisure facilities are homogenous } \\
\text { and short-lived }\end{array}$ \\
\hline & Perception of Middle Eastem culture \\
\hline & Inflation \\
\hline
\end{tabular}


Table 4: SWOT analysis of tourisın development in Egypt

\begin{tabular}{|c|c|}
\hline Strengths & IVeakness \\
\hline Huge supply of cultura! unigue attractions & $\begin{array}{l}\text { Lack of manpower training, lack of quality control over tourism } \\
\text { busincss }\end{array}$ \\
\hline Central location bedwecn Europe, Asin and Africa & Instability in the Middle East \\
\hline Favorable climale ald the year & Lack of basic and tourism infristructure \\
\hline Cheap (Price Competítiveness) & Limiled service industry \\
\hline Attractive sun and beaches & Poltution and lack of clcanlincss \\
\hline Environmental altractions: deserts, oases, nalural protected arcas & Tourist exploitation and lack of awarencss lowards tourists \\
\hline $\begin{array}{l}\text { Massive expansion in tourism facilities and its supportive } \\
\text { infrasinucture }\end{array}$ & Poor roads networks and transportation mcans \\
\hline Scveral touristic meqa projects & Limited financial markeling expenditures \\
\hline \multirow[t]{2}{*}{ Great gavenument interest } & Traffic congestion and noisc \\
\hline & Standard of airport facilitics and lack of public toile1s \\
\hline Opportunities & Threats \\
\hline Encourage overall positive atritude towards tourism/iourists & Perecption of Middle Eastem culturc \\
\hline Collect and disseminate tourism data & Negative cnvironment effects \\
\hline $\begin{array}{l}\text { Promote to relevant markets, especially MICE (Mectings, } \\
\text { lncentive. Conference, Exhibition) }\end{array}$ & $\begin{array}{l}\text { Neglect behavior for some man-power of some tourism related } \\
\text { serviecs }\end{array}$ \\
\hline Exploit medical and healhh tourism & Unawareness of nationals \\
\hline $\begin{array}{l}\text { Devcloping people with enomous social problems (cducation, } \\
\text { health, awareness...) }\end{array}$ & Economic instability (Inflation, unemployment...) \\
\hline Gain public and ipvestor's confidence & Social pap between rich and poor \\
\hline \multicolumn{2}{|l|}{ Deccnimalization and modemization of tourism administration } \\
\hline \multicolumn{2}{|l|}{ Integration of the lourism sustainable dcrclopment plan } \\
\hline New tourism niche areas & \\
\hline
\end{tabular}

5- Choice of policles and strategies The practice of various countries in their tourism development proves that govemment policies towards tourisin are the key of its tourisin development. Therefore some policics and strategies should have priorities in execution such as:

- Governments must take responsibility for maintaining an economic environment conductive to attract business. This might be enhanced by private investment in -cmployee's education and training and by enabling staff to visit a wide array of tourism locations so as to broaden their development experiences.

- Egypt must improve the efficiency of the service industry, upgrade service quality and cut scrvice costs.

- Drive to expand the world's intemational tourism market by: 1) Knowing clearly the market demand so as 10 detennine the target market and work out corresponding marketing strategies. 2) Sending information in time to the target market. Both tacties and techniques of marketing are equally important. Therefore, more input should be made, and more money should be spent on market sludy and effective promotion.

- Expand tourist's expenditure; the way of growth should be altered from quantity to efficiency. In addition, more efforis should be made to prolong the length of stay, expand opportunities or visitors to consusne and encourage them to spend more money in the country.

- Special interest should be given to increase locals' awareness towards tourists and lourism benefits. This should be achieved not only by execution of projects such as "Tourisin National Awareness Project", but aiso by enhancing the locals' economic and social circunstances.

- It is necessary to develop special interest tourism products such as convention and conference business travels and incentive tours.

- Offering more convenience and preferential treatments for tourists such as generalized preferential systems, the provision of proper shopping facilities for tourists as shopping is referred to as being one of the most enjoyable leisure time activities, and the development of specific souvenirs and gifts (Zhang etal.2000).
- Regional infrastructure needs to be carefully planned in order to extend and hamess life cycles.

- It is apparent that successful tourism planning requires both the involvement and participation of residents in the destination areas. The rural interior needs must be developed to provide the "ideal" rural tourism product that allows tourists to stay with the local people, so breaking down local- tourist resentment. implementation of training programmes and development of products that support the local communities as well as development of eco and rural tourism (Eccles and Costa, 1996)are cnucial.

- Sustainability needs to evolve through effective planning, where guidelines are set on the breadth, and the depth of development. Therefore, developing a product that sits in hannony with the local environment is very imporiant. Furthermore, locals need to be educated about sustainability in the hope of training people to preserve the product that actually offers them a living.

Developing niche areas is another strategy. In receiving tourism products one can note that these sonetimes have a short life span resulting in a stream of new offerings into the market place.

- For the future of tourism, of major importance demographically is the growh of old travelers. The main implication arising from demographic change is likely to be the increased number of senior citizens in the developed countries of the world. Therefore, interest should be given 10 offer a product that matches with this potential market. Moreover, holidays have become realities, thus helping industry to extend its product's life cycle.

- Egypt should adhere to the general principal of giving priority to inbound tourism in order to eam more foreign exchange. Outbound tourism should be developed in a planned way. Egyptians should be encouraged to practice domestic travel first.

\section{6- Conclusion}

Though Egypt has a long history in courism and enjoys diverse, various and incomparable atiractions, Dubai has surpassed in in terms of perfomance in tourism development putting into consideration the limited natural/heritoge attractions in Dubai. 
Concerning the destination marketing, Dubai outpcrforms Egypt as shown in the competition report. . Effective promotion, stbstantial marketing expenditures and appropriate tining of campaigns are needed. Extensive market research should be done to attract potential markets such as China that will become a key source of outbound tourism by 2020, supplying 100 million travelers (WTO, 2007).

As we have seen despite the linited attractions in Dubaj, they succeeded to create an attractive destination offering various types of attractions.

Human resources are fundamental factor to be developed. Education, training, economic and social development to manpower is essential. These interests should also be offered to the public to increase their awareness towards tourism which will make the trip to Egypt a more safe, secure and satisfactory trip as without public support few will be achieved.

Tourrism related services such as transportation is another chalienge for Egypt's tourism. Although Egyptian government is massively expanding its tourisin facitities, as well as modenizing its supporing infrastructure, effective and extensive development ${ }^{*}$ projects should be executed.

Efforts also should be given to enhance the image of Egypt intemationally.

Serious efforts should be made to calculate the net profit of toutrisin in Egypt. This is why the Egyptian government should give interest to this sensitive point by applying tourism satellite accounts to access "the feasibility of such development's projects.

Realization of the official targets towards tourism needs constant efforts, not only from the tourism sectors but also from the whole society.

\section{7- References}

- $\therefore$ Deen, ME (2007). "Medical tourism in UAE to generate Dl77b by 2010", Gulf News, April 29, p. 38.

- Ail Hakeen, M. (2007). "Tourism contributes .18\% of Dubai GDP per yeas", Gulf News, available at:

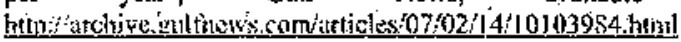
(accessed February 14,2007 )

- Am Cham Egypt, 2008. American Chanter of Commerce in Egypt-Business studies and analysis centre-Tourism sector development in Egypt.nilu (accessed August, 2008).

- Anastasiou, A. (2007). "Collaboration in new areas strengthens ties", Gulf News, available at

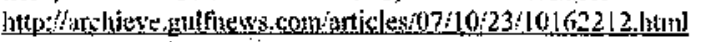
(accessed Oclober 23, 2007).

- Aziz, H. (1995). "Understanding attacks on tourism in Egypt", Tourism Management, Vol.16, No.2, pp. 91-95.

- Baik. D.A. (2007). "Playing policy instruments to curb flying inflation", Gulf News- Comments and Analysis, February 13, p.51.

- Balakrishnan, M.S. (2008), "Dubai- a star in the enst- A case study in strategic destination branding". Journal of Place Management and Developnent, Vol. J, No. 1, pp.62-91.

- Balasubramanian, S. (1992). Arabian Gulf outbound, Travel and Tourism Analyst, Vol.6, pp.26-46.

- Balasubramanian, S. (1993). United Arab Emirates, International Tourism reports, Vol.3, pp.29-54.

- BBC. (2004). Country Protile: United Arab Emirates, BBC News

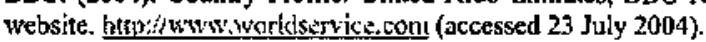

- Bolussa, D. (2003). Dubai: the search for identily. In People, Places and Sustainability, Moser G. (eds.), Hogrefe and Huber: Seattle; pp.51-60.

- Buhalis, D. (2000). "Marketing the competitive destination of the future", Tourism Management, Vol. 21, pp. 97-1 16.

- Burton, R. (1995). Travel geography. Pituan: London.

- Cairo intemational Airport, (2008). Available at: Wikipedia-the free encyclopedja.mht. (Accessed August 2008).

- Central Bank of Egypt (2008). In "Econonic and Social performance indicators", July 2008. Information and Decision
Support Centre, Egyptian Ministers' Council, available at: kww s: idsc. s0r,eg (accessed August 2008).

- Clenents, F, 1998, United Arab Entirates, Clio Press: Oxford.

- Crookston, M. (1998). "Conservation and regeneration: two case studies in the Arab world", in Embracing and Managing Change in Tourism, Laws E, Moscatdo G, Faulkner B (eds.), Roulledge: ncw York; pp.264-280.

- Deebes, Y. (2002). "Tourism globalization (Developed and developing countries' reality", Egyptian Assembly for Innovation and Development, Alexandria.

- Destinations in Egypt, (2008). Destination in Egypt, our travel guide to Egypt including most Egyplian cities. mht: (Accessed August, 2008). mist

- Dew, P. (2007). "Exhibitions and trade fairs. In doing business with the United Arab Emirates, Dew P, Shoult A (Eds) ${ }^{1}$ Kogan Page: London, pp.184-187.

- Ditcham, R. (2007). "Dubai's target to lure tourists is chailengeable but achievable", Gulf News, March 19, p.39.

- DTCM. (2000). Consolidated Report, Department of Tourism and Commerce Marketing: Dubai.

- DTCM. (2004a). Dubai Visitor survey 2002-03, Department of Tourism and Conmerce Marketing: Dubai.

- DTCM. (2004b) Hotel Statistics 1994-2003 and Hotel Apartments Statisties 1996-2003, Department of Tourism and Commerce Marketing: Dubai.

- DTCM. (2004c). Departnent of Tourism and commerce Marketing website. hun://www, duhaitourism, ae (actessed 18 May 2004).

- DTCM. (2004d). Dubai showcase iraspiring tourism growth, Press Release, $7 \mathrm{May}$, Department of Tourism and Commerce Marketing: Dubai.

- DTCM. (2005). Developments in selected major govemment and private sector, Department of Tourism and Conmerce Marketing: Dubai.

- DTCM. (2007). One Stop Information Centre, Department of Tourism and Commerce Markeling, available at: kn'u dubaituntisolate.

- Dubaj Healthcare City (2007), available at

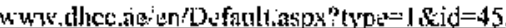

- Dwyer, L. and Forsyth, P. (1997). "Impacts and benefits of MICE tourism: a framework for analysis", Tourism Economics, Vol.3, No. I, pp.21-38. Eccles, G. and Costa, J. (1996). "Perspectives on tourism development", International Journal of Contemporary Ifospitality Manayement, Vol. 8, No.7, pp.44-51.

- EIU. (1993). "United Arab Envirates",'The Economist Intelligence Unit, International Tourism Reports, No. 3, pp. 29-54.ElU. (2003a). Middle East Tourism: a tough 20 months, The Economist Intelligence Unit Viewswite, 310.

- EIU. (2003b). Middle East Tourism: UAE in a world of its own, Executive Briefing, The Economist Jntelligence Unit: London; 310 .

- EIU. (2005a). United Arab Emirates Country Profile 2005, the Economist lntelligence Unit: London.

- EIU. (2005b). United Arab Entrates Country Report 2005, The Econonist Intelligence Unit: London.

- EIU. (2005c). UAE Historica! Data- Dubai Tourism, The Economist Intelligence Unit Viewswire, 41.

- Elezaby, A. (2008a). "The cost of the Egyptian tourism promotion campaign "within Atab countries" is USS3 million", availsble at: hain:i/salahamabingaktobblog.conl (accessed 10 July 2008).

- Elezaby, A. (2008b). Discover Alex, available at: http://wwwdiscoveralex.com/News/News.asp?id=4731. (Accessed August 2008).

- Elmasry- Elyoun, (2007). "The pronotion authority organizes a ceremony in France to stimulate tourism". Elmasry- Elyoum

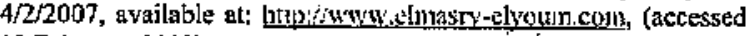
12 February 2008).

- Elnagar, M. (2008). "Tourism cantpaigns informatics- Refused awareness campaign and objectionable international campaignFailed campaign1", Elahram Newspaper, 18 October.

- Emirates Airlines (2007). "Enirate airline official web page", available at: www,emirate.com.

- FCO. (2004). United Atab Emirates Country Profile, United Kingdom Foreign and Commonwealth Office website. httpifown fico zov uk (accessed 4 June 2004).

- Finn, A. and Erdem, T. (1995). "The economic impact of mejanulti mall. Estimation issues in the case of West Edmonton Mall", Tourism Management, Vol. 16, No.5, pp.367-373. 
- Future Brands (2006). "Couniry brand index, 2006", available al: future brand.con/03showease/leadership/cbi/pdf/cbi_eng06.pdf.

- Fyall, A. Gartod, B. and Leask, A. (2003). Managing visitor attractions: New directions. Oxford: Butterworth Heinemann.

- Greene, G. and O'Loughlin, S. (1999). "Hotels in the Middle East: trends and opportunities", Travel and Tourism Analyst, Vol.4, pp. 65-88.

- Gulf News. (2004a). Hospitality rolls out red carpet. 4 Mny.

- Gulf News. (2004b). Dubailand to attract Dh20b. 10 Febriary.

- Gulf News. (2004c). Dubai clearing the decks to attract ecotourists. 16 June.

- Gulf News. (2007a). "MoE to begin household inconie and expense survey", Gulf News, Februaty 12, p.37.

- Gulf News. (20076). "Dubai summer surprises 2007 outlines new strategic plan", Gulf News, April 29, p.38.

- Gulf Nows. (2007c). "2007 sales will account for $8 \%$ of Dubaj's GDP". available at:

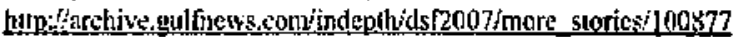
92.html (accessed December 8, 2006).

- Gunn. C. (2004). Tourism planning: Basics, concepts, cases. Taylor and Francis: London.

- Henderson, J.C. (2003). "Managing tourism and Islam in Peninsular Malaysia", Tourisnn Management, Vol. 24, No. 4, pp. 447-456.

- Henderson, J.C. (2006). "Tourism in Dubai: Overcoming barriers to destination development", Intemationa] Joumal of Tourism Research, Vol.8, pp.87-99.

- Ilotels. (2004). "Special report: Europe, Middle East, Africa", Hotels, June, pp.35-40.

- Husain, S. (2007a). "Mideast tourism likely to see \$3tr investment by 2020 ", Gulf Ncws, May 1, p.46.

- Husain, S. (2007b). "Dubaj to have the world's biggest retail zone", Gulf News, May 6, p.34.

- IMD (2005), World Competitive Yearbook 2005, available al:

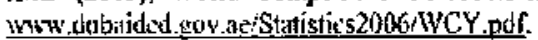

- Information and decision support centre, (2007). Information Renorts, Information and Decision Support Centre, Egyptian Minsisters' Council, Vol.12, December 2007, available at:

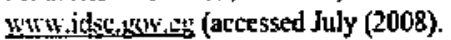

- Johns, N. and Mattson, J. (2005). "Destination development through entrepreneurship: A comparison of two cases", Tourism Management, Vol. 26, pp. 605-616.

- Kawach, N. (2004). "UAE citizens emerge top spenders in the Arab world". Gulf News, available at:

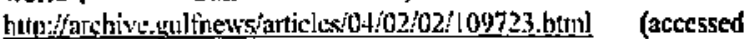
February 2, 2004).

- Kelly. M. (1998). "Jordan's potenlial tourism development ", Annals of Tourism Research, Vol.25, No. 4, pp. 904-918.

- May. V. (1991). "Tourism, environment and development. Values, sustainability and stewardship", Tourism Managenent, Vol. 12. No. 2, pp. 112-118.

- Middle East Moritor (2007). "Dubai accounts for $80 \%$ of total rionoil trade". Middle East Monitor, Vol.17, No.4, p.5.

- Ministry of Civil Aviation, (2006). In Ministry of Tourism, (2006), "Tourism in Figures: Egypt", Information and Computer Cenler, Arab Republic of Egypt.

- Ministry of Communication and Information Technology (2008). In Economic and Social Indicators Report. Information and Decision Support Centre, Egyptian Ministers' Council, July 2008, available at: whas idsc. looveg (accessed August 2008).

- Ministry of Economic Development, 2008. In "Economic and Sacial performance indicators". July 2008. Infomation and Decision Support Centre, Egyptian Ministers' Council, avaikable at: muw.idsc. goveg (accessed Angust 2008).

- Ministry of Planning. (2002). "Dubai gross domestic product of factor cost by economic sectors", governnent of Dutbai: Dubai.

- Ministry of Tourism, (2006). Tourism in Figures: Egypt. Information and Compuler Center, Arub Republic of Egypt.

- Ministry of Tourism, (2007). Tourism in Figures: Egypt. Information and Computer Center, Arab Republic of Egypt.

- Ministry of Tourism, (2008). In "Economic and Social perfornance indicators", July 2008. Infornation and Decision Support Centre,
Egyptian Ministers' Councih available at: mmidisc.soy.eg (accessed August 2008).

- Mintel. (2002). The Middle East, Country reports, Vol,4, pp, l-29.

- Molavi, A. (2007). "Dubaj- the world's hottest property- Sudden City", National Geographic, January, pp.94-113.

- Mugbil, I. (1997). "The Asjan conferences, meetings and incentives market", Travel and Tourism Analyst, Vol.2, pp.38-56.

- Poirier, R.A. (1997). "Political risk analysis and tourism". Annals of Tourism Research, Vol.21, No. 3, gp. 675-686.

- Peisley, T. (2000). "The cruise industry in the Arabian Gulf and Indian ocean", Travel and Tourism Analyst, Vol, 1, pp. 3-17.

- Poirier, R.A. (1997). "Political risk analysis and tourisn", Annals of Tourism Research, Vol. 21, No. 3, pp. 675-686.

- Prideaux, B. (2000). "The role of transport system in destination development", Tourism Managentent, Vol. 21, pp.53-63.

- Rahman, S. (2007a). "Dubai poised to open 'new page in history'Mohamed strategic plan will be service based economy", Gulf News, February 4, p.l.

- Rahman, S. (2007b). "Tourism comprises 30\% of Dubai GDP". Gulf News, May 4, pp.3 [-34.

- Rahrnan, S. (2007c). "Dubai records higher 2006 cargo volumes Than Heathrow Aisport", Gulf News, March 12, p.40.

- Retail ME (2006a). "Lure of the mall stronger than ever", Retail ME Annual Edjtion, pp.51-3.

- Reuters. (2004). Lebanon rules. The Straits Times, Vol. 17, August.

- Sharpley, R. (2002). "The challenges of economic diversification through tourism: The case of Abu Dhabi", International Joumal of Tourism Research, Vol. 4, pp. 221-235.

- The Financial Times. (2004). Amrani in 41 bn hotels plan, 23 February.

- The General Invesiment and Free Zone Authority, 2008. In "Econornic and Social performance indicators". July 2008. Infomation and Decision Support Centre, Egyptian Ministers* Council, available at: wWw. idsc. sov. wy (accessed August 2008).

- The observer. (2005). Ski in the desert? It could only happen in Dubai, The observer 20 November.

- Thompson, S. (2006). "A year of phenomenal growth", Retail ME Annual Edition, pp,45-8.

- UAE. (2005). Travel Guide. United Arab Emirates website. hltp:finwuy.uze.ore.ac (accessed 10 December).

- UAE Interact (2007a), "Tourism contributes $18 \%$ to Dubai GDP per year", UAE Inlerach, available at: www uneinteract.cominew'defanltasp?'] $\mathrm{D}=$ ? + ? (accessed February 14, 2007).

- UAE Interact (2007b), "Buildiug Dubai's image", UAE Interact, available at: whw useinlenacl.cnmincwide fuult.ass? (accessed January 16, 2007).

- Wahab, S. (2000). "Middle East". In Tourism and Hospitality in the $21^{\text {st }}$ Century, Lockwood A. and Medlik S. (Eds), Buttenworth Heinemann: Oxford, pp.163-171.

- Weaver, D, and Lawton, L. (2002). Tourism management, John Wiley: Sydney.

- WTO. (2005). Methodological Notes. World Tourism Organization: Madrid.

- WTO. (2005). Tourism highlights edition 2005. World Tourism Organization: Madrid.

- WTO (2007). "China: \#1 outbonnd tourism market by 2020", World Travel and Tourism Council, available at: www.buyusa,gov/china/en/tourism,html /_sectionl

- WTTC. (2007). "Executive summary: travel and tourism navigating the path ahead", World Travel and Tourism Council. London, available

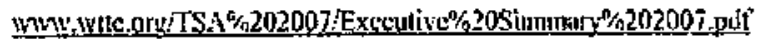
(accessed March 8, 2007).

- Zawya (2007). "Sheikh Mohammed Bin Rashed Al Maktoum launches foundation to promote humsn development with Dhs. 37 billion endowment", Zawya, available at:

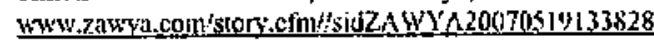
(aceessed May 19. 2007).

- Zhang, G., Pine R. and Zhang H.Q. (2000). "China"s intemational tourism development: Present and future", Intemational Jourmal of Temporary Hospitalicy Management, Vol. 12. No.5. pp. 282-290. 
تمظيم التنمبة السياحية في مصر عن طريث فحص

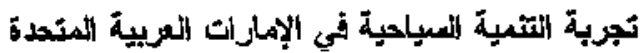

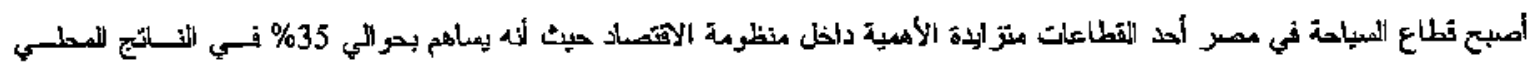

الإجمائمي و 12.6\% في حجم العهالة.

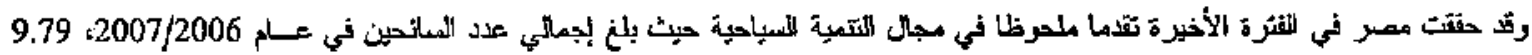
مليون مائح.

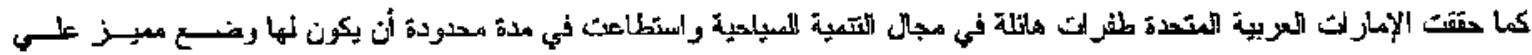
خريطة السباهة اللولية.

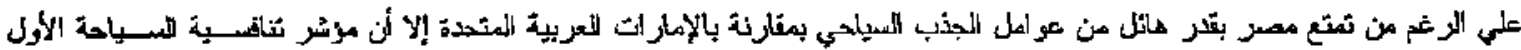

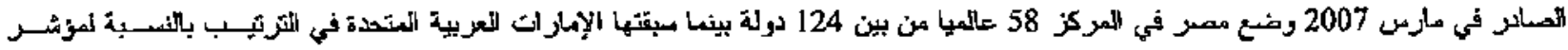

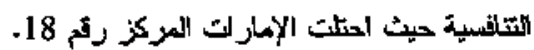

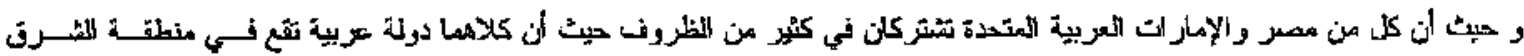

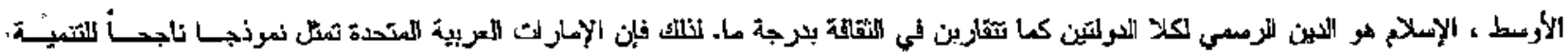

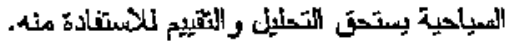

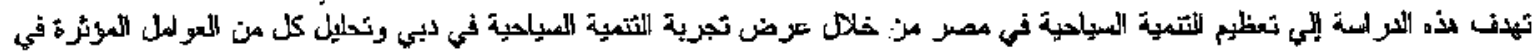

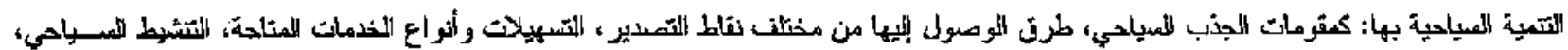

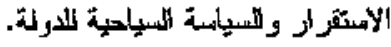

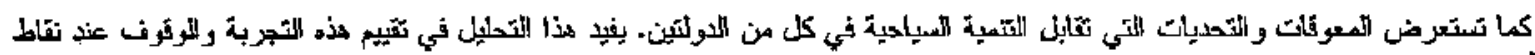

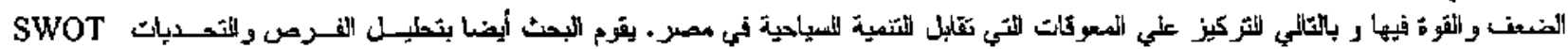
Analysis كلك من التتمية العياحية لكل صن الثوالتين.

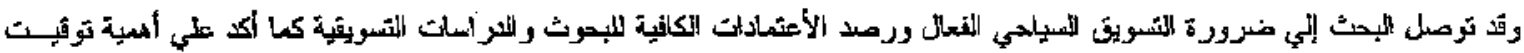

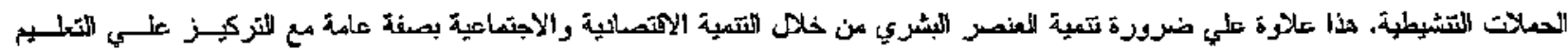
والتريب.

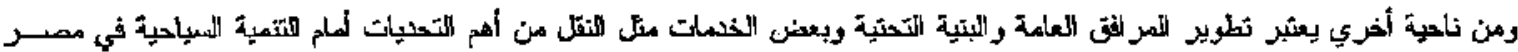

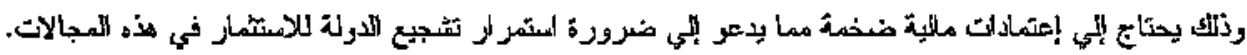

